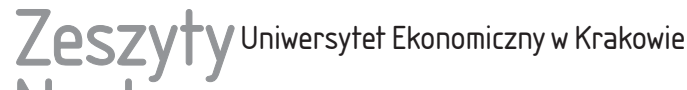 Naukowe
}

$6(966)$

ISSN 1898-6447

Zesz. Nauk. UEK, 2017; 6(966): 5-27

DOI: 10.15678/ZNUEK.2017.0966.0601

\section{Analiza przyczyn występowania różnic w podejściu do napływu imigrantów w państwach członkowskich Unii Europejskiej}

\section{Streszczenie}

Liczba nielegalnych imigrantów napływających do Unii Europejskiej od kilku lat gwałtownie wzrasta. Stosunek władz państw członkowskich UE i obywateli tych państw do napływu nielegalnych imigrantów wykazuje znaczne zróżnicowanie. W artykule podjęto próbę wyjaśnienia przyczyn występowania różnic w podejściu do problemu napływu imigrantów w państwach członkowskich Unii Europejskiej. Pod uwagę wzięto kilka wybranych kryteriów ilościowych. Przeanalizowano prognozy demograficzne do 2080 r. oraz zaproponowano dwa wskaźniki: wskaźnik obciążenia imigracyjnego (WOI) oraz wskaźnik obciążenia gospodarek napływem imigrantów (WOG), które mają wyjaśniać stosunek do napływu obcej ludności. Z przeprowadzonych rozważań wynika, że przyczyn pozytywnego nastawienia lub niechęci wobec napływu imigrantów do państw członkowskich Unii Europejskiej nie da się wyjaśnić, stosując tylko wskaźniki ilościowe.

Słowa kluczowe: Unia Europejska, kryzys migracyjny, teorie migracji, badania migracji. Klasyfikacja JEL: F15, J10, J19.

Helena Tendera-Właszczuk, Uniwersytet Ekonomiczny w Krakowie, Wydział Ekonomii i Stosunków Międzynarodowych, Katedra Europejskiej Integracji Gospodarczej, ul. Rakowicka 27, 31-510 Kraków, e-mail: tendera@uek.krakow.pl 


\section{Wprowadzenie}

Liczba nielegalnych imigrantów napływających do Unii Europejskiej od kilku lat gwałtownie wzrasta. Stanowiska państw członkowskich UE wobec napływu imigrantów, podobnie jak ich polityka, znacznie się różnią ${ }^{1}$. Najczęściej problem ten rozpatrywany jest z punktu widzenia barier w asymilacji imigrantów i skuteczności odmiennych sposobów ich integracji z miejscową społecznością. Wśród barier często wymienia się gorsze warunki socjalne napływowej ludności, występowanie marginalizacji i wykluczenia społecznego imigrantów, co powodować może niepokoje społeczne i zamieszki na tle etnicznym.

Wielu badaczy przyczyn niechęci wobec napływu imigrantów upatruje w obawie o zachowanie podstawowych wartości Unii Europejskiej, takich jak: pokój, demokracja, prawa człowieka, tolerancja i solidarność, które wydają się być zagrożone. To z kolei często jest źródłem eurosceptycyzmu. Eurosceptycy podkreślają zbyt liberalne podejście unijnych instytucji do problemu napływu ludności o odmiennym systemie wartości.

Inni badacze w napływie imigrantów widzą zagrożenie dla tożsamości kulturowej UE, a jeszcze inni postrzegają kryzys migracyjny jako zagrożenie dla funkcjonowania projektu europejskiego, czego wyrazem jest bezsilność instytucji unijnych i impas w negocjacjach dotyczących rozwiązania tego palącego problemu oraz niemożność osiągnięcia wspólnego stanowiska przez państwa członkowskie.

W niniejszym artykule podjęto próbę wyjaśnienia przyczyn występowania różnic w podejściu do problemu napływu ludności obcego pochodzenia (rozumianej jako obywatele spoza UE) ${ }^{2}$ w państwach członkowskich Unii Europejskiej. Pod uwagę wzięto kilka wybranych kryteriów ilościowych. Przeprowadzono analizę prognoz demograficznych do 2080 r. oraz zaproponowano dwa autorskie wskaźniki: wskaźnik obciążenia imigracyjnego (WOI) oraz wskaźnik obciążenia gospodarek napływem imigrantów (WOG), które mają wyjaśniać akceptację napływu obcej ludności lub jej brak.

Hipoteza pierwsza głosi, że pozytywne podejście do napływu imigrantów występuje w państwach, w których prognozowany jest największy spadek ludności do 2080 r. Hipoteza druga mówi, że pozytywne nastawienie do napływu imigrantów występuje w państwach, w których wskaźnik obciążenia imigracyjnego

${ }^{1}$ Oczywiście należałoby odróżnić nastawienie do uchodźców od nastawienia do nielegalnych imigrantów w państwach członkowskich. Takie statystyki nie są jednak dostępne. W związku z tym rozważania zawarte w niniejszym artykule dotyczyć będą nastawienia do napływu ludności spoza Unii. Podobnie należałoby odróżnić nastawienie rządów od nastawienia obywateli państw członkowskich. Przyjęto jednak założenie, że politycy są odpowiedzialni za realizowanie woli suwerena i rozliczani w kolejnych wyborach.

${ }^{2}$ Niezależnie od ich statusu (nielegalni imigranci, uchodźcy), dalej zwani imigrantami. 
jest niższy od średniej unijnej. Hipoteza trzecia mówi, że pozytywne nastawienie do napływu imigrantów występuje w państwach, w których wskaźnik obciążenia gospodarczego napływem obcej ludności jest niższy od średniej unijnej.

Celem niniejszego artykułu jest weryfikacja tych hipotez i ocena skuteczności zaproponowanych wskaźników.

\section{Teoretyczne i prawne aspekty migracji - przegląd literatury}

Kryzys migracyjny w Unii Europejskiej wyraźnie pokazuje, że mamy do czynienia równolegle z napływem nielegalnych imigrantów i uchodźców. Z analizy literatury przedmiotu wynika, że studia nad uchodźstwem nie mają teoretycznych podstaw. Istniejące teorie migracji, zarówno ekonomiczne, geograficzne, jak i socjologiczne [Janicki 2007], wyrywkowo ujmują problem uchodźstwa, analizując jego specyfikę jako jeden z czynników wpływających na podjęcie decyzji o opuszczeniu własnego kraju. Używa się tu często zamiennie terminów „migracje polityczne” lub „migracje przymusowe”, co nie odzwierciedla specyfiki tego zjawiska we współczesnym świecie globalnych konfliktów i zagrożeń.

Dla celów niniejszej analizy warto przyjrzeć się podziałowi migracji ze względu na kryterium dobrowolności na migracje dobrowolne i przymusowe. Migracje przymusowe do niedawna utożsamiane były jedynie $\mathrm{z}$ występowaniem niesprzyjających czynników ekonomicznych i demograficznych (złe warunki życia, przeludnienie) lub politycznych (wojny, konflikty, prześladowania) w kraju pochodzenia. Ostatnio coraz częściej wśród przyczyn emigracji wymienia się czynnik ekologiczny, a mianowicie zmiany klimatyczne, wyczerpywanie się zasobów naturalnych, głównie wody, pustynnienie terenów, które dawniej były uprawne. Poważnym problemem jest również zalewanie przez powodzie terenów gęsto zaludnionych czy podnoszenie się poziomu wód oceanów na skutek wzrostu temperatury na naszej planecie [Tendera-Właszczuk 2016].

Migracje ekonomiczne mają najczęściej charakter dobrowolny i są najczęściej występującym zjawiskiem we współczesnym świecie. Migracje o charakterze politycznym i ekologicznym występują rzadziej i są związane z wystąpieniem nieprzewidzianych okoliczności. Decyzje o migracjach o podłożu ekonomicznym podejmowane są przez dłuższy czas, często za namową rodziny, natomiast wojny, konflikty narodowościowe czy klęski żywiołowe powodują pozostawienie całego dobytku w kraju pochodzenia i natychmiastową ucieczkę do miejsc/krajów, w których takie zagrożenia nie występują.

Migracje przymusowe, o charakterze politycznym, powodują masowe przemieszczanie się ludności z obszarów objętych konfliktem i ludność ta jest objęta ochroną międzynarodową w dowolnym państwie, sygnatariuszu konwencji genewskiej. 
Teorie migracji najczęściej analizują motywy opuszczenia kraju z punktu widzenia emigranta. Skupiają się więc na przyczynach takich decyzji i subiektywnych ocenach ich własnej sytuacji (najczęściej ekonomicznej), jak również na ocenie tej sytuacji przez członków gospodarstwa domowego lub lokalnej wspólnoty ${ }^{3}$.

W niniejszej pracy podjęto próbę oceny wybranych teorii migracji z punktu widzenia interesów państw przyjmujących migrantów. Znane teorie migracji, np. teoria E.S. Lee [1966 i 1972], wyjaśniają głównie przyczyny migracji zarobkowych, wskazując na czynniki push - wypychające (odnoszące się do kraju pochodzenia), czynniki pull - przyciągające (odnoszące się do kraju docelowego), czynniki osobiste i przeszkody pośrednie. Suma tych czynników wpływa na decyzje migracyjne. E.S. Lee stwierdza, że migranci powinni przemieszczać się do kraju, który umożliwi im maksymalizację dobrobytu. Podkreśla się często, że to silny bodziec, np. względy bezpieczeństwa czy czynniki polityczne, decydują ostatecznie o opuszczeniu kraju (czynniki push), stąd teoria ta tylko częściowo wyjaśniać może specyficzną sytuację uchodźców. Podobnie nowa ekonomika migracji, upatrująca ich przyczyn w poprawie sytuacji finansowej i dywersyfikacji źródeł dochodów w rodzinie/grupie społecznej, nie wyjaśnia przyczyn uchodźstwa.

S. Castels, M.J. Miller [2011] oraz D.S. Massey i in. [1993] wskazują na zróżnicowanie procesów migracyjnych we współczesnym świecie i podkreślają rolę czynników geopolitycznych. Podejście to może w pewnym stopniu wyjaśniać przyczyny uchodźstwa, nie wyjaśnia jednak nastawienia krajów przyjmujących do ludności napływowej.

Pozytywne nastawienie do przyjmowania migrantów może natomiast wyjaśniać teoria zwana potocznie teorią centrum-peryferie [Wallerstein 1974], w myśl której następuje eksploatacja peryferii przez kraje bogate, szukające możliwości zaspokojenia potrzeb swojego rynku pracy.

Zaprezentowane teorie migracji w niewielkim stopniu wyjaśniają przyczyny, które skłaniają państwa do otwarcia się na przyjmowanie uchodźców. Istnieje więc potrzeba tworzenia nowych teorii opisujących to zjawisko [Kelm i Tendera-Właszczuk 2008, 2011].

Badanie uchodźstwa jest trudne i skomplikowane głównie z powodu braku dostosowanej do współczesnych uwarunkowań globalnych, jednoznacznej i powszechnie akceptowanej definicji uchodźcy. Brak takiej definicji jest źródłem wielu problemów. Jedynie bowiem prawna identyfikacja uchodźcy gwarantuje mu ochronę w prawie międzynarodowym. To ważne z punktu widzenia państwa

3 Teoria neoklasyczna mówi o poszukiwaniu przez migrantów kraju zapewniającego im najwyższy poziom życia. Przedstawicielem takiego poglądu jest G. Borjas [1989]. Z kolei nowa ekonomika migracji podkreśla znaczenie grupy społecznej w podejmowaniu decyzji migracyjnych jednostki. 
przyjmującego: uznanie osoby za uchodźcę powoduje przyznanie mu prawa do wieloletniego pobytu.

Potocznie uchodźcą nazywamy osobę, która pozostaje poza granicami kraju pochodzenia i chroni się przed prześladowaniami ze względów religijnych, politycznych, etnicznych, skutkami działań wojennych, klęskami żywiołowymi lub nędzą. Trzeba jednak pamiętać, że termin ten został precyzyjnie określony w dwóch dokumentach międzynarodowych.

Konwencja genewska z 1951 r. [Konwencja dotycząca statusu... 1951] oraz protokół nowojorski z 1967 r. [Protokół dotyczący statusu... 1967] stanowią prawną podstawę przyznawania statusu uchodźcy i opisują fundamentalne prawa uchodźców. Dokumenty te odwołują się do definicji uchodźcy: „[...] termin «uchodźca» stosuje się do osoby, która [...] na skutek uzasadnionej obawy przed prześladowaniem z powodu swojej rasy, religii, narodowości, przynależności do określonej grupy społecznej lub z powodu przekonań politycznych przebywa poza granicami państwa, którego jest obywatelem, i nie może lub nie chce z powodu tych obaw korzystać z ochrony tego państwa, albo która nie ma żadnego obywatelstwa i znajdując się na skutek podobnych zdarzeń poza państwem swojego dawnego stałego zamieszkania, nie może lub nie chce z powodu tych obaw powrócić do tego państwa" [Konwencja dotycząca statusu... 1951].

Wymienione dokumenty przyznają ochronę także tym osobom, co do których przesłanki nadania statusu uchodźcy powstały po opuszczeniu przez nich kraju pochodzenia. Obecnie stosowana definicja uchodźcy z 1951 r. nie odzwierciedla współczesnych przyczyn uchodźstwa (tzw. arabska wiosna, wojna w Syrii). Wyraźnie widać, że definicja prawna uchodźcy, obowiązująca niezmiennie od ponad 60 lat, jest nieadekwatna do sytuacji międzynarodowej i wymaga przeformułowania ze względu na zmieniające się przyczyny uchodźstwa [Kelm i Tendera-Właszczuk 2011].

Należy podkreślić, że zgodnie z prawem międzynarodowym również osoby, w stosunku do których nie można w sposób bezpośredni zastosować konwencji genewskiej, mają prawo do ochrony na podstawie przepisów prawa wewnętrznego państwa członkowskiego.

Należy również odróżnić status uchodźcy od statusu azylanta. Prawo do azylu, czyli udzielenia w określonych okolicznościach schronienia cudzoziemcom, jest zagwarantowane w prawie narodowym, w konstytucjach wielu państw. W prawie międzynarodowym nie ma jednak powszechnie przyjętej definicji azylu. Udzielenie azylu jest zatem całkowicie uzależnione od decyzji konkretnego państwa. Status uchodźcy może być nadany zarówno przez państwo, jak i przez organ międzynarodowy, jakim jest UNHCR (Wysoki Komisarz Narodów Zjednoczonych ds. Uchodźców). Status azylanta, w przeciwieństwie do statutu uchodźcy, nie zapewnia ochrony międzynarodowej [Białocerkiewicz 2002, Florczak 2002]. 
Warunki, które muszą zostać łącznie spełnione, by uzyskać status uchodźcy, są następujące:

- cudzoziemiec przebywa poza krajem pochodzenia,

- nie korzysta z ochrony innego państwa,

- żywi uzasadnioną obawę przed prześladowaniem z powodu rasy, religii, narodowości, przynależności do określonej grupy społecznej lub poglądów politycznych,

- nie może lub nie chce korzystać z ochrony państwa pochodzenia.

Zgodnie z Europejską konwencją o ochronie praw człowieka i podstawowych wolności, każdy człowiek w razie prześladowania może ubiegać się o azyl lub korzystać z niego w innych krajach. Protokół czwarty do tej konwencji zawiera zakaz zbiorowego wydalania cudzoziemców.

Kolejną kategorią prawną jest ochrona czasowa cudzoziemców. Jest ona nadawana w sytuacji masowego napływu imigrantów spowodowanego brakiem bezpieczeństwa w kraju pochodzenia. Na mocy ochrony czasowej cudzoziemcy otrzymują prawo legalnego pobytu w kraju przyjmującym na określony czas, tj. do czasu, gdy w państwie pochodzenia zostanie im zagwarantowane bezpieczeństwo. Procedura ta jest o wiele krótsza, mniej skomplikowana i mniej kosztowna dla państwa przyjmującego niż procedura azylowa.

\section{Napływ imigrantów do państw członkowskich Unii Europejskiej - skala zjawiska}

Od początku działań wojennych w Afganistanie i Iraku mieszkańcy tych krajów przesiedlali się do państw sąsiadujących - Pakistanu oraz Iranu. W konsekwencji Pakistan oraz Iran stały się państwami z największą populacją uchodźców na świecie.

Od 2014 r. następował napływ niekontrolowanej migracji mieszkańców Afryki, w tym głównie obywateli Syrii, Erytrei oraz Afganistanu, poszukujących możliwości osiedlenia się w Unii Europejskiej. Obecnie najwięcej aplikacji o azyl w Unii Europejskiej składają osoby pochodzące z Syrii. Uchodźcy z tego kraju stanowią 25\% wszystkich osób starających się o azyl w krajach Europejskiego Obszaru Gospodarczego (EOG). Dużą część stanowią osoby pochodzące z Afganistanu, których wnioski o azyl stanowią 11\%. Liczni są również uchodźcy z Iraku, Kosowa, Albanii, Erytrei oraz Serbii. Wojna, niepokoje społeczne bądź zamieszki na tle etnicznym zmuszają ich do poszukiwania schronienia poza granicami kraju. Oceniając Unię Europejską jako obszar pokoju, dobrobytu i poszanowania praw człowieka, docierają aż do granic UE [The Mediterranean Migration... 2015]. W sytuacji masowego napływu imigrantów granice zewnętrzne Unii okazały się 
nieszczelne, a budowany od 1985 r. system strefy Schengen okazał się nieskuteczny. Unia Europejska w obliczu skali napływu migrantów podejmuje działania, do których jest zobligowana konwencją genewską i protokołem nowojorskim wobec napływających uchodźców, odmawia natomiast przyjmowania imigrantów ekonomicznych, poszukujących lepszych warunków życia w Europie Zachodniej.

Na rys. 1 przedstawiono dane dotyczące liczby wniosków o udzielenie azylu w państwach członkowskich Unii Europejskiej w latach 1998-2015. Do 2013 r. liczba osób składających wnioski wynosiła od 197 tys. do 424 tys. rocznie. W latach 1998-2001 odnotowano tendencję rosnącą, a w latach 2002-2006 liczba wniosków azylowych wyraźnie się zmniejszała. W latach 2007-2013 liczba osób wnioskujących o udzielenie azylu prawie się podwoiła (431 tys.). Przełomowy był 2014 r., kiedy to liczba wniosków wzrosła do 626 tys. W 2015 r. liczba ta ponownie się podwoiła. Z szacunków UNHCR wynika, że w pierwszej połowie 2016 r. do Unii Europejskiej przybył $1 \mathrm{mln}$ imigrantów.

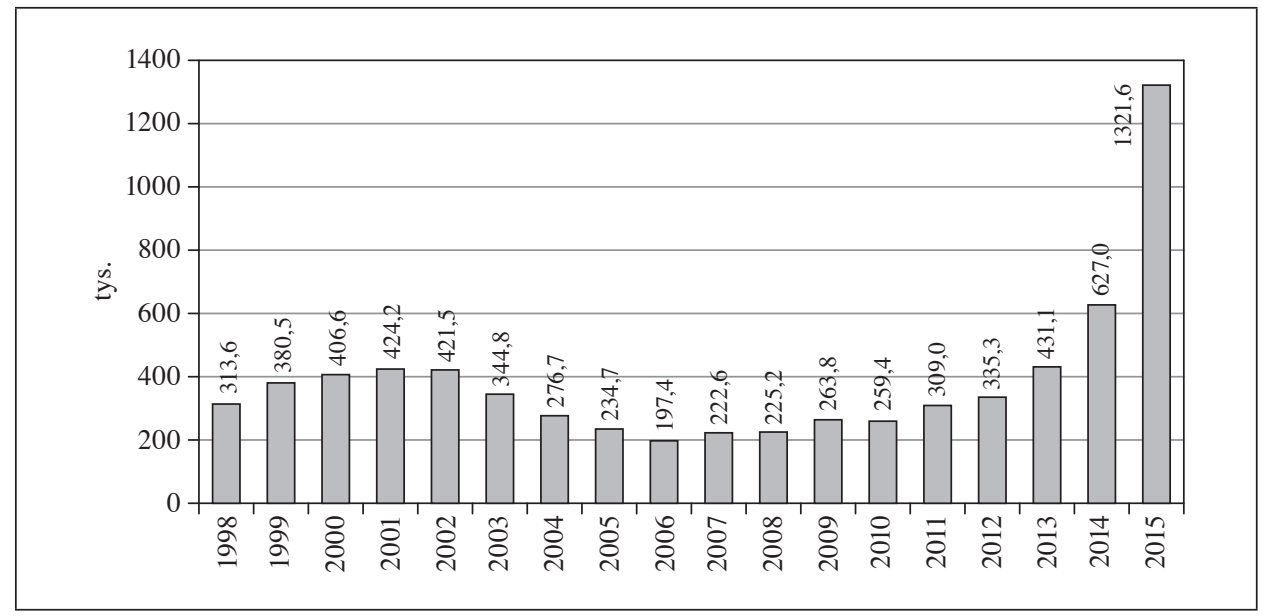

Uwaga: dane dla Chorwacji od 2013 r.

Rys. 1. Liczba imigrantów składających wnioski o przyznanie azylu w Unii Europejskiej w latach 1998-2015

Źródło: opracowanie własne na podstawie danych Eurostatu.

W tabeli 1 przedstawiono dane na temat liczby osób, które napłynęły do Unii Europejskiej i złożyły wniosek o przyznanie azylu w poszczególnych państwach członkowskich w latach 1998-2015. Liczba wniosków azylowych złożonych w 2015 r. wyniosła ponad 1 mln 321 tys. Najwięcej wniosków złożono w Niemczech - blisko 476,5 tys., na Węgrzech - ponad 177 tys., w Szwecji - ponad 162,4 tys., w Austrii - ok. 88 tys., we Włoszech - 84 tys., i we Francji - 75,7 tys., co stanowi ok. $80 \%$ ogółem złożonych w Unii Europejskiej wniosków. 
Tabela 1. Liczba imigrantów składających wnioski o azyl w poszczególnych krajach Unii Europejskiej w latach 1998-2015

\begin{tabular}{|c|c|c|c|c|c|c|c|c|}
\hline Wyszczególnienie & 1998 & 1999 & 2000 & 2001 & 2002 & 2003 & 2004 & 2005 \\
\hline UE-27 (UE-28) & 313645 & 380450 & 406585 & 424180 & 421470 & 344800 & 276675 & 234675 \\
\hline Austria & 13805 & 20130 & 18285 & 30125 & 39355 & 32360 & 24635 & 22460 \\
\hline Belgia & 21965 & 35780 & 42690 & 24505 & 18800 & 13585 & 12400 & 12575 \\
\hline Bułgaria & 835 & 1350 & 1755 & 2430 & 2890 & 1320 & 985 & 700 \\
\hline Chorwacja & $\cdot$ & · & $\cdot$ & $\cdot$ & $\cdot$ & $\cdot$ & $\cdot$ & · \\
\hline Cypr & 225 & 790 & 650 & 1620 & 950 & 4405 & 9675 & 7715 \\
\hline Czechy & 4085 & 7355 & 8790 & 18095 & 8485 & 11400 & 5300 & 3590 \\
\hline Dania & 5700 & 6530 & 10345 & 12510 & 5945 & 4390 & 3235 & 2280 \\
\hline Estonia & 25 & 25 & 5 & 10 & 10 & 15 & 10 & 10 \\
\hline Finlandia & 1270 & 3105 & 3170 & 1650 & 3445 & 3090 & 3575 & 3595 \\
\hline Francja & 22375 & 30905 & 38745 & 47290 & 51085 & 59770 & 58545 & 49735 \\
\hline Grecja & 2950 & 1530 & 3085 & 5500 & 5665 & 8180 & 4470 & 9050 \\
\hline Hiszpania & 4935 & 8405 & 7925 & 9490 & 6310 & 5765 & 5365 & 5050 \\
\hline Holandia & 45215 & 39275 & 43895 & 32580 & 18665 & 13400 & 9780 & 12345 \\
\hline Irlandia & 4625 & 7725 & 10940 & 10325 & 11635 & 7485 & 4265 & 4305 \\
\hline Litwa & 160 & 145 & 305 & 425 & 365 & 395 & 165 & 100 \\
\hline Luksemburg & 1710 & 2930 & 625 & 685 & 1040 & 1550 & 1575 & 800 \\
\hline Łotwa & 35 & 20 & 5 & 15 & 25 & 5 & 5 & 20 \\
\hline Malta & 160 & 255 & 160 & 155 & 350 & 455 & 995 & 1165 \\
\hline Niemcy & 98645 & 94775 & 78565 & 88285 & 71125 & 50565 & 35605 & 28915 \\
\hline Polska & 3425 & 3060 & 4660 & 4480 & 5170 & 6810 & 7925 & 5240 \\
\hline Portugalia & 355 & 305 & 225 & 235 & 245 & 115 & 115 & 115 \\
\hline Rumunia & 1235 & 1665 & 1365 & 2280 & 1000 & 885 & 545 & 485 \\
\hline Słowacja & 505 & 1320 & 1555 & 8150 & 9745 & 10300 & 11395 & 3550 \\
\hline Słowenia & 335 & 745 & 9245 & 1510 & 650 & 1050 & 1090 & 1550 \\
\hline Szwecja & 12840 & 11220 & 16285 & 23500 & 33015 & 31355 & 23160 & 17530 \\
\hline Węgry & 7120 & 11500 & 7800 & 9555 & 6410 & 2400 & 1600 & 1610 \\
\hline Wielka Brytania & 46015 & 71160 & 80315 & 71365 & 103080 & 60045 & 40625 & 30840 \\
\hline Włochy & 13100 & 18450 & 15195 & 17400 & 16015 & 13705 & 9630 & 9345 \\
\hline
\end{tabular}

Źródło: opracowanie własne na podstawie danych Eurostatu. 


\begin{tabular}{|c|c|c|c|c|c|c|c|c|c|}
\hline 2006 & 2007 & 2008 & 2009 & 2010 & 2011 & 2012 & 2013 & 2014 & 2015 \\
\hline 197410 & 222635 & 225150 & 263835 & 259400 & 309040 & 335290 & 431090 & 626960 & 1321600 \\
\hline 13350 & 11920 & 12715 & 15780 & 11045 & 14420 & 17415 & 17500 & 28035 & 88160 \\
\hline 8870 & 11575 & 15165 & 21615 & 26080 & 31910 & 28075 & 21030 & 22710 & 44660 \\
\hline 500 & 815 & 745 & 855 & 1025 & 890 & 1385 & 7145 & 11080 & 20365 \\
\hline · & · & - & · & $\cdot$ & $\cdot$ & - & 1075 & 450 & 210 \\
\hline 4540 & 6780 & 3920 & 3200 & 2875 & 1770 & 1635 & 1255 & 1745 & 2265 \\
\hline 2730 & 1585 & 1645 & 1235 & 775 & 750 & 740 & 695 & 1145 & 1515 \\
\hline 1960 & 2225 & 2350 & 3720 & 5065 & 3945 & 6045 & 7170 & 14680 & 20935 \\
\hline 5 & 15 & 15 & 40 & 35 & 65 & 75 & 95 & 155 & 230 \\
\hline 2275 & 1405 & 3670 & 4910 & 3085 & 2915 & 3095 & 3210 & 3620 & 32345 \\
\hline 30750 & 29160 & 41840 & 47620 & 52725 & 57330 & 61440 & 66265 & 64310 & 75750 \\
\hline 12265 & 25115 & 19885 & 15925 & 10275 & 9310 & 9575 & 8225 & 9430 & 13205 \\
\hline 5295 & 7195 & 4515 & 3005 & 2740 & 3420 & 2565 & 4485 & 5615 & 14780 \\
\hline 14465 & 7100 & 15250 & 16135 & 15100 & 14590 & 13095 & 13060 & 24495 & 44970 \\
\hline 4240 & 3935 & 3855 & 2680 & 1935 & 1290 & 955 & 945 & 1450 & 3275 \\
\hline 145 & 125 & 520 & 450 & 495 & 525 & 645 & 400 & 440 & 315 \\
\hline 525 & 425 & 455 & 480 & 780 & 2150 & 2050 & 1070 & 1150 & 2505 \\
\hline 10 & 35 & 55 & 60 & 65 & 340 & 205 & 195 & 375 & 330 \\
\hline 1270 & 1380 & 2605 & 2385 & 175 & 1890 & 2080 & 2245 & 1350 & 1845 \\
\hline 21030 & 19165 & 26845 & 32910 & 48475 & 53235 & 77485 & 126705 & 202645 & 476510 \\
\hline 4225 & 7205 & 8515 & 10590 & 6540 & 6885 & 10750 & 15240 & 8020 & 12190 \\
\hline 130 & 225 & 160 & 140 & 155 & 275 & 295 & 500 & 440 & 895 \\
\hline 380 & 660 & 1175 & 960 & 885 & 1720 & 2510 & 1495 & 1545 & 1260 \\
\hline 2850 & 2640 & 895 & 805 & 540 & 490 & 730 & 440 & 330 & 330 \\
\hline 500 & 370 & 255 & 190 & 240 & 355 & 295 & 270 & 385 & 275 \\
\hline 24320 & 36205 & 24785 & 24175 & 31850 & 29650 & 43855 & 54270 & 81180 & 162450 \\
\hline 2115 & 3420 & 3175 & 4665 & 2095 & 1690 & 2155 & 18895 & 42775 & 177135 \\
\hline 28320 & 27905 & . & 31665 & 24335 & 26915 & 28800 & 30585 & 32785 & 38800 \\
\hline 10350 & 14055 & 30140 & 17640 & 10000 & 40315 & 17335 & 26620 & 64625 & 84085 \\
\hline
\end{tabular}


W porównaniu z 2006 r. liczba osób starających się o azyl w UE wzrosła blisko siedmiokrotnie. Podobny wzrost nastąpił w Austrii i Szwecji. We Włoszech wzrost był ośmiokrotny. Największy wzrost zaobserwowano na Węgrzech (liczba wniosków azylowych wzrosła 88,5 razy) oraz w Niemczech (ponad 22 razy).

Badania opinii publicznej przeprowadzone jesienią 2016 r. w państwach członkowskich wskazują, że 56\% obywateli Unii negatywnie ocenia imigrację osób spoza UE [Komunikat prasowy... 2016].

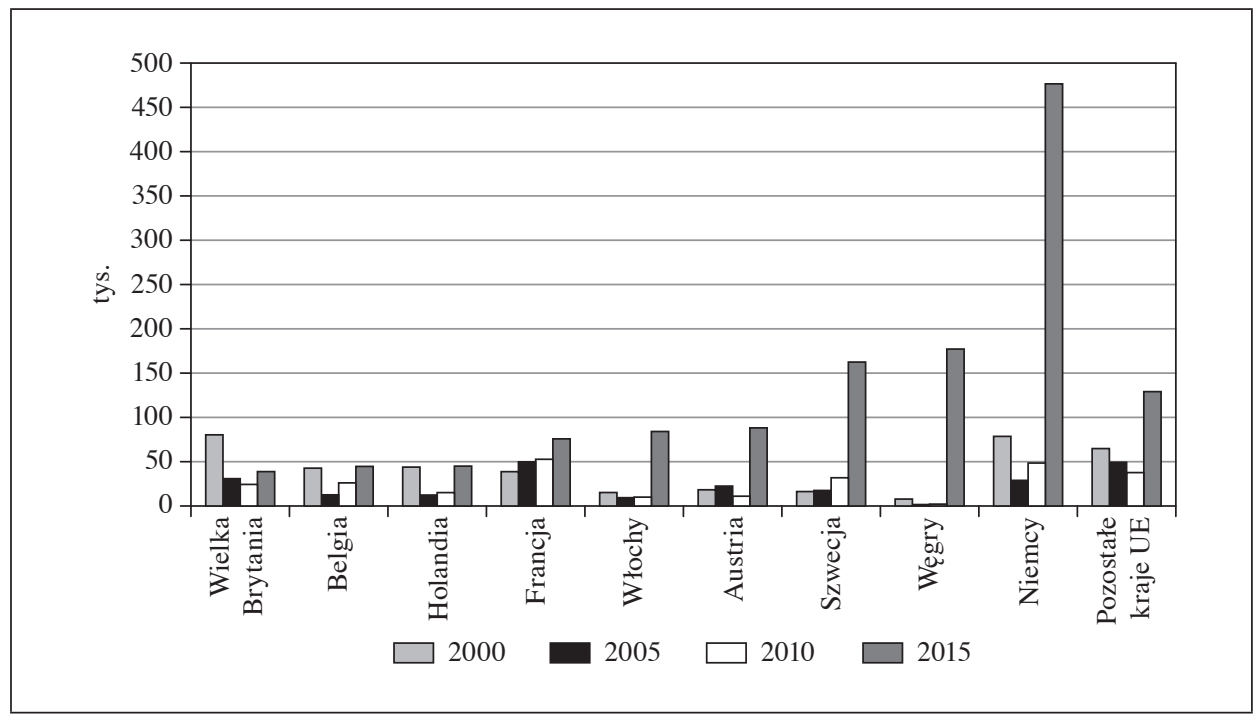

Rys. 2. Kraje najczęściej wybierane przez imigrantów według liczby ubiegających się o azyl w latach 2000, 2005, 2010 i 2015

Źródło: opracowanie własne na podstawie danych Eurostatu.

Rys. 2 prezentuje dane dotyczące krajów najczęściej wybieranych przez imigrantów. W 2000 r. były to Wielka Brytania i Niemcy. W 2015 r. w Niemczech złożono $36 \%$ wszystkich wniosków azylowych, najwięcej ze wszystkich państw członkowskich Unii Europejskiej. Kolejne miejsca zajmują Węgry $(13,4 \%)$, Szwecja (12,3\%), Austria (6,7\%), Włochy $(6,3 \%)$ oraz Francja (5,7\%). Należy zaznaczyć, że spośród 1321600 wniosków o azyl złożonych w państwach członkowskich UE w 2015 r. tylko 26 415, tj. niecałe 2\%, zostało rozpatrzonych pozytywnie ${ }^{4}$.

${ }^{4}$ Według danych Eurostatu. 


\section{Prognozy demograficzne a podejście do napływu ludności obcego pochodzenia w wybranych państwach członkowskich}

Na przełomie XX i XXI w. zaczęły się pojawiać niezwykle niepokojące prognozy, dotyczące trendów demograficznych w Europie. Powszechna stała się opinia, że Europa zaczyna się wyludniać, a w stosunkowo niedługiej perspektywie liczba białej ludności na świecie zacznie znacząco maleć [Kelm 2014].

W tabeli 2 przedstawiono prognozy liczby ludności w państwach członkowskich Unii Europejskiej do 2080 r. Z ich analizy wynika, że sytuacja demograficzna w państwach członkowskich Unii Europejskiej będzie zróżnicowana. W 13 z nich nastąpi wzrost lub niewielki wzrost liczby ludności (Belgia, Dania, Irlandia, Francja, Cypr, Luksemburg, Hiszpania, Włochy, Malta, Austria, Finlandia, Szwecja i Wielka Brytania ${ }^{5}$. W kilku krajach prognozy zakładają utrzymanie się do 2080 r. liczby ludności na poziomie zbliżonym do tego z 2015 r. (Czechy, Holandia i Słowenia).

W 12 państwach członkowskich nastąpi znaczny spadek liczby ludności, od $12 \%$ do 36,5\% w stosunku do stanu z 2015 r. Największy spadek ma wystąpić na Litwie (36,5\%). Do 2050 r. liczba ludności w tym kraju ma się zmniejszyć o $34,16 \%$. W przypadku trzech krajów - Łotwy, Bułgarii i Portugalii, prognozuje się spadek liczby ludności odpowiednio o $32 \%, 31,6 \%$ oraz $31,4 \%$ w stosunku do roku bazowego. W Grecji i Słowacji przewiduje się spadek odpowiednio o 29,9\% oraz $28,6 \%$. Duży, lecz nieco mniejszy spadek liczby ludności wystąpi w Polsce i Estonii (odpowiednio o 23,16\% oraz 21,5\%). W Niemczech prognozuje się spadek o 19\%, w Chorwacji o 18,2\%, a w Rumunii o 17,94\%. Listę zamykają Węgry, gdzie do 2080 r. ma nastąpić spadek liczby ludności o blisko $12 \%$ (por. rys. 3).

$\mathrm{Z}$ analizy wynika, że wśród państw najbardziej zagrożonych znacznym spadkiem liczby ludności jest aż dziewięć nowych państw członkowskich Unii Europejskiej, które uzyskały członkostwo w latach 2004 i 2007. W liczbach bezwzględnych największym spadkiem zagrożone są Niemcy (15 mln 300 tys. osób). Polska, z prognozowanym spadkiem liczby ludności o $8 \mathrm{mln} 918$ tys., zajmuje w tym rankingu drugie miejsce. Łącznie w 12 państwach członkowskich objętych analizą liczba ludności ma się zmniejszyć o 42 mln 106 tys. ${ }^{6}$

$\mathrm{Na}$ podstawie analizy nastawienia społeczeństw tych państw można stwierdzić, że najwyższe poparcie dla napływu ludności obcego pochodzenia występuje w Portugalii (48\%), Chorwacji (41\%), Niemczech (40\%) oraz Rumunii (35\%).

${ }^{5}$ Niezwykle skomplikowana i nadal niejasna sytuacja związana z planowanym wyjściem Wielkiej Brytanii z Unii Europejskiej (Brexit) skłania do analizowania sytuacji demograficznej z uwzględnieniem dotychczasowego składu członkowskiego Unii.

${ }^{6}$ Obliczenia własne na podstawie danych zawartych w tabeli 2. 


\begin{tabular}{|c|c|c|c|c|c|c|c|c|c|c|c|c|c|c|c|c|c|c|c|c|c|}
\hline $\begin{array}{l}\stackrel{\infty}{\infty} \\
\stackrel{\text { }}{2}\end{array}$ & 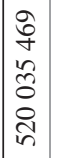 & $\begin{array}{l}0 \\
\infty \\
\infty \\
\tilde{c} \\
\tilde{d} \\
n \\
\sigma\end{array}$ & 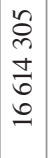 & 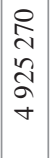 & 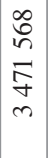 & $\begin{array}{l}n \\
n \\
n \\
n \\
-\end{array}$ & $\begin{array}{l}\hat{j} \\
\hat{j} \\
o \\
2 \\
\hat{\sigma}\end{array}$ & $\begin{array}{l}\stackrel{2}{\sigma} \\
\hat{\sigma} \\
\stackrel{\hat{\sigma}}{\sigma}\end{array}$ & $\mid \begin{array}{l}\mathfrak{g} \\
\mathcal{J} \\
\stackrel{\widehat{े}}{\delta} \\
-\end{array}$ & $\begin{array}{l}\tilde{N} \\
\tilde{\infty} \\
\tilde{\infty} \\
\tilde{\sigma}\end{array}$ & $\begin{array}{l}\infty \\
\stackrel{0}{0} \\
\stackrel{2}{*} \\
\stackrel{5}{\infty} \\
\infty \\
\infty\end{array}$ & 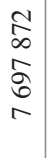 & 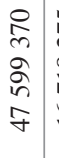 & 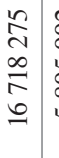 & $\begin{array}{l}2 \\
\alpha \\
\check{\alpha} \\
\infty \\
n\end{array}$ & $\begin{array}{l}\stackrel{2}{尺} \\
\vec{J} \\
-\end{array}$ & $\begin{array}{l}\stackrel{0}{2} \\
\text { Ǹ } \\
\stackrel{\infty}{\sim} \\
\end{array}$ & $\begin{array}{l}n \\
\text { n } \\
\bar{n} \\
-\end{array}$ & $\begin{array}{l}\hat{\sigma} \\
\stackrel{\infty}{+} \\
\stackrel{\infty}{+}\end{array}$ & 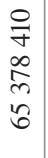 & \\
\hline$\stackrel{?}{\stackrel{2}{s}}$ & 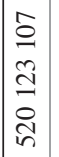 & 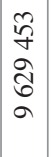 & 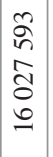 & \begin{tabular}{l}
\multirow{2}{0}{} \\
$\hat{n}$ \\
0 \\
0 \\
$n$ \\
$n$
\end{tabular} & $\begin{array}{l}g \\
\stackrel{g}{1} \\
\tilde{D} \\
i \\
n \\
m\end{array}$ & $\begin{array}{l}0 \\
0 \\
+ \\
8 \\
0 \\
-\end{array}$ & 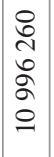 & 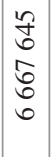 & 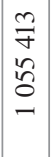 & $\begin{array}{l}\tilde{n} \\
\tilde{N} \\
\tilde{N} \\
\tilde{0}\end{array}$ & $\begin{array}{l}\hat{a} \\
\hat{\sigma} \\
\hat{0} \\
\hat{n}\end{array}$ & $\begin{array}{l}\stackrel{J}{~} \\
\sigma \\
\vec{b} \\
\infty\end{array}$ & 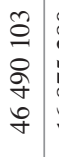 & $\begin{array}{l}\infty \\
\infty \\
\sim \\
n \\
\infty \\
0 \\
0\end{array}$ & $\begin{array}{l}\hat{\sigma} \\
2 \\
\tilde{N} \\
\tilde{n} \\
n\end{array}$ & $\begin{array}{c}\hat{0} \\
\infty \\
\varnothing \\
\infty \\
\infty \\
-1\end{array}$ & $\begin{array}{l}\tilde{n} \\
\stackrel{\infty}{\sim} \\
-\end{array}$ & 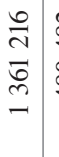 & 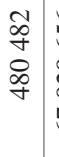 & 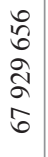 & \\
\hline : & $\begin{array}{l}\tilde{\tilde{N}} \\
\tilde{n} \\
\tilde{f} \\
\tilde{2} \\
\tilde{N} \\
\tilde{n}\end{array}$ & $\begin{array}{l}\overrightarrow{7} \\
\infty \\
0 \\
0 \\
a\end{array}$ & 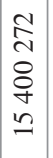 & 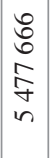 & 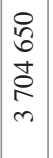 & $\begin{array}{l}\stackrel{\Xi}{\tilde{N}} \\
\stackrel{\Xi}{=} \\
-\end{array}$ & $\begin{array}{c}0 \\
\stackrel{2}{0} \\
\vec{\infty} \\
0 \\
= \\
=\end{array}$ & $\begin{array}{l}0 \\
0 \\
\infty \\
0 \\
\delta \\
n \\
0\end{array}$ & $\begin{array}{c}\infty \\
\infty \\
\infty \\
\infty \\
\mathbb{\delta} \\
\delta \\
-\end{array}$ & 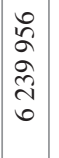 & \begin{tabular}{l}
$\infty$ \\
$\infty$ \\
$a$ \\
\multirow{n}{n}{} \\
$i$
\end{tabular} & $\begin{array}{l}\text { f } \\
+ \\
\infty \\
\infty \\
n \\
\infty\end{array}$ & 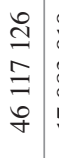 & 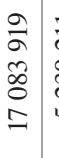 & 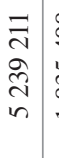 & $\begin{array}{l}\infty \\
\stackrel{+}{+} \\
\sim \\
\infty \\
-\end{array}$ & $\begin{array}{l}\text { ô } \\
\text { n } \\
\text { లે } \\
=\end{array}$ & $\begin{array}{l}\hat{s} \\
\stackrel{2}{ } \\
\infty \\
\check{n} \\
-\end{array}$ & \begin{tabular}{l}
$\stackrel{0}{8}$ \\
8 \\
$o$ \\
\multirow{f}{f}{}
\end{tabular} & 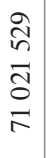 & \\
\hline ஜ̊ & $\mid \begin{array}{l}2 \\
\infty \\
\hat{\Sigma} \\
\tilde{n} \\
2 \\
\tilde{n}\end{array}$ & 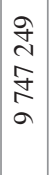 & $\begin{array}{l}\underset{⿱}{\sim} \\
\infty \\
\stackrel{2}{\sim} \\
\dot{J}\end{array}$ & 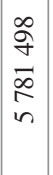 & $\begin{array}{l}n \\
o \\
o \\
\infty \\
\approx \\
\infty \\
n \\
n\end{array}$ & $\begin{array}{l}\tilde{N} \\
\tilde{n} \\
\tilde{n} \\
\delta \\
-\end{array}$ & $\begin{array}{l}n \\
2 \\
\hat{N} \\
\hat{\sigma} \\
=\end{array}$ & 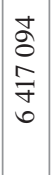 & 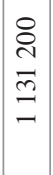 & $\begin{array}{l}0 \\
2 \\
2 \\
8 \\
0 \\
0 \\
0\end{array}$ & 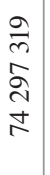 & $\begin{array}{l}o \\
+ \\
0 \\
+ \\
m \\
a\end{array}$ & $\begin{array}{l}n \\
b \\
n \\
f \\
n \\
i\end{array}$ & 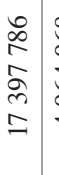 & 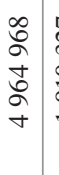 & 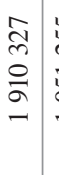 & $\begin{array}{l}n \\
\tilde{n} \\
\overrightarrow{0} \\
-\end{array}$ & 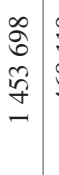 & $\begin{array}{l}9 \\
\Xi \\
\infty \\
\dot{f}\end{array}$ & $\begin{array}{l}\frac{n}{\pi} \\
\vec{N} \\
\frac{\pi}{\pi}\end{array}$ & 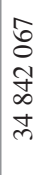 \\
\hline $\begin{array}{l}\text { Pे } \\
\text { ते }\end{array}$ & 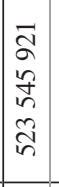 & $\begin{array}{l}\hat{0} \\
\infty \\
\infty \\
n \\
0 \\
0 \\
\sigma\end{array}$ & $\begin{array}{l}\vec{J} \\
\partial \\
\infty \\
\sigma \\
\ddot{\sigma}\end{array}$ & $\begin{array}{l}0 \\
m \\
\infty \\
\infty \\
0 \\
0\end{array}$ & $\begin{array}{l}\hat{n} \\
\alpha \\
\hat{n} \\
\alpha \\
n\end{array}$ & 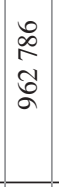 & 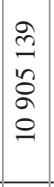 & 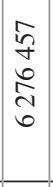 & 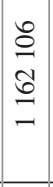 & $\begin{array}{l}t \\
n \\
n \\
n \\
0 \\
0\end{array}$ & $\begin{array}{l}0 \\
0 \\
0 \\
2 \\
\mathbb{2}\end{array}$ & \begin{tabular}{l}
$m$ \\
\multirow{0}{0}{} \\
+ \\
$\tilde{n}$ \\
$a$
\end{tabular} & $\begin{array}{l}\bar{\sigma} \\
\bar{\sigma} \\
\dot{\sigma} \\
\dot{f}\end{array}$ & $\begin{array}{l}\stackrel{2}{c} \\
\tilde{n} \\
\tilde{b} \\
=\end{array}$ & \begin{tabular}{l}
\multirow{2}{0}{} \\
0 \\
8 \\
0 \\
0 \\
$\forall$
\end{tabular} & 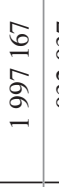 & $\begin{array}{l}\hat{\kappa} \\
\tilde{\sigma}\end{array}$ & \begin{tabular}{l}
$\infty$ \\
\multirow{2}{\infty}{} \\
$\stackrel{m}{n}$ \\
$=$
\end{tabular} & 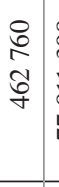 & 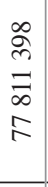 & 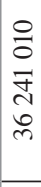 \\
\hline ণ্ণি & 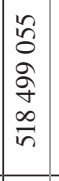 & $\begin{array}{l}\stackrel{N}{a} \\
\mathbb{N} \\
\stackrel{N}{N} \\
\sigma\end{array}$ & 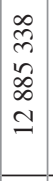 & $\begin{array}{l}n \\
2 \\
\infty \\
o \\
f \\
\sigma\end{array}$ & 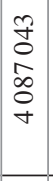 & $\begin{array}{l}\infty \\
2 \\
0 \\
\tilde{2} \\
\Omega\end{array}$ & 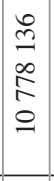 & $\begin{array}{l}\infty \\
\infty \\
\infty \\
2 \\
\tilde{\delta} \\
0\end{array}$ & 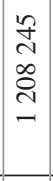 & \begin{tabular}{|c|} 
\\
$⿱$ \\
$\infty$ \\
0 \\
$\infty$ \\
$\infty$ \\
$\infty$ \\
$n$
\end{tabular} & $\begin{array}{l}n \\
0 \\
o \\
2 \\
\tilde{m} \\
尺\end{array}$ & $\begin{array}{l}0 \\
+ \\
0 \\
0 \\
8 \\
0 \\
0\end{array}$ & 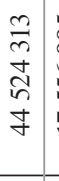 & 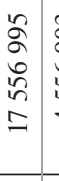 & 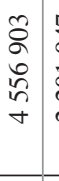 & 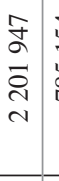 & $\begin{array}{l}\frac{1}{2} \\
2 \\
\infty \\
\infty\end{array}$ & 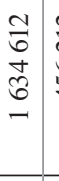 & 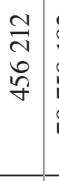 & 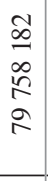 & $\begin{array}{l}\frac{n}{5} \\
n \\
\hat{n} \\
n \\
m\end{array}$ \\
\hline ๙ి & 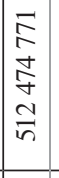 & $\begin{array}{l}0 \\
\sigma \\
\tilde{\alpha} \\
\infty \\
\infty\end{array}$ & 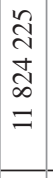 & $\begin{array}{l}\infty \\
\infty \\
n \\
\hat{n} \\
\sigma \\
\sigma\end{array}$ & $\begin{array}{l}0 \\
\infty \\
\infty \\
\infty \\
ٍ \\
\ddots\end{array}$ & 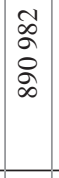 & \begin{tabular}{l}
$\infty$ \\
$\infty$ \\
$\infty$ \\
\pm \\
\multirow{J}{0}{} \\
0 \\
0
\end{tabular} & $\begin{array}{l}\stackrel{1}{1} \\
\infty \\
\stackrel{2}{\hat{n}} \\
i n\end{array}$ & 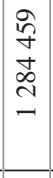 & $\begin{array}{l}\tilde{N} \\
\infty \\
\infty \\
\sigma \\
n\end{array}$ & 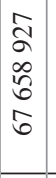 & $\begin{array}{l}\varsubsetneqq \\
\xi \\
\hat{\wp} \\
\varrho\end{array}$ & \begin{tabular}{l}
$\curvearrowright$ \\
$\infty$ \\
\multirow{2}{\gamma}{} \\
$i$ \\
$f$
\end{tabular} & $\begin{array}{l}\bar{\Omega} \\
\tilde{2} \\
\approx \\
\Sigma\end{array}$ & $\begin{array}{l}\stackrel{\infty}{\varrho} \\
\stackrel{0}{0} \\
+\end{array}$ & 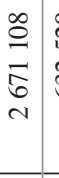 & $\begin{array}{l}\text { ते } \\
\text { กิ } \\
\text { రુ }\end{array}$ & $\begin{array}{l}\infty \\
\infty \\
0 \\
\infty \\
\infty \\
-1\end{array}$ & 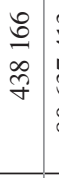 & 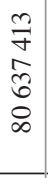 & శ్ర \\
\hline$\stackrel{n}{\stackrel{N}{~}}$ & 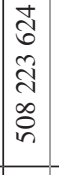 & $\begin{array}{l}\vec{\infty} \\
0 \\
\vec{n} \\
n \\
\infty\end{array}$ & 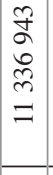 & $\begin{array}{l}\vec{\sigma} \\
\sigma \\
\sigma \\
r\end{array}$ & 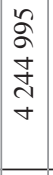 & $\begin{array}{l}n \\
\delta \\
m \\
\infty\end{array}$ & $\begin{array}{l}0 \\
d \\
0 \\
0 \\
\tilde{n} \\
0\end{array}$ & 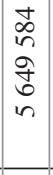 & $\begin{array}{l}\tilde{n} \\
\stackrel{n}{n} \\
\bar{n} \\
=\end{array}$ & \begin{tabular}{|c|}
0 \\
$\infty$ \\
+ \\
$\infty$ \\
$\stackrel{f}{f}$ \\
$n$
\end{tabular} & 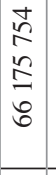 & $\begin{array}{l}\mathfrak{n} \\
\alpha \\
\hat{s} \\
\hat{a} \\
0\end{array}$ & 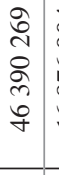 & $\begin{array}{l} \pm \\
0 \\
0 \\
\infty \\
\infty \\
0 \\
0\end{array}$ & 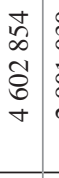 & 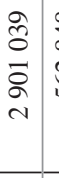 & 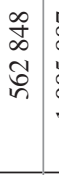 & $\begin{array}{l}\infty \\
\infty \\
\infty \\
\infty \\
\infty \\
-1\end{array}$ & 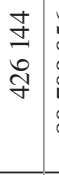 & 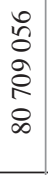 & \\
\hline $\begin{array}{l}3 \\
0 \\
0\end{array}$ & 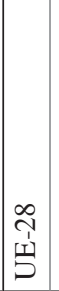 & 吾 & $\begin{array}{l}\frac{\pi}{00} \\
\frac{0}{0} \\
\infty\end{array}$ & 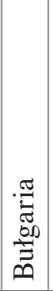 & 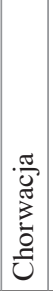 & 芯 & 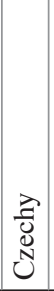 & 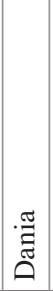 & 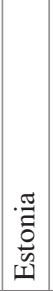 & 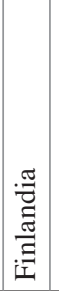 & 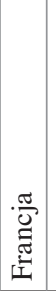 & $\begin{array}{l}\text { 莺 } \\
\stackrel{0}{0}\end{array}$ & 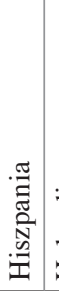 & 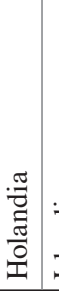 & 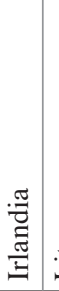 & 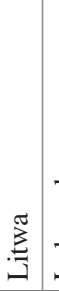 & 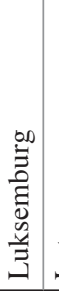 & 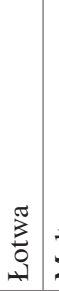 & $\frac{\pi}{\tilde{J}}$ & 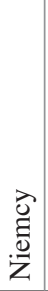 & \\
\hline
\end{tabular}




\begin{tabular}{|c|c|c|c|c|c|c|c|c|}
\hline $\begin{array}{l}\stackrel{0}{\circ} \\
\stackrel{\sim}{0}\end{array}$ & $\mid$\begin{tabular}{l}
$\infty$ \\
$\infty$ \\
$\infty$ \\
$\cdots$ \\
\hdashline \\
$\sim$
\end{tabular} & $\begin{array}{l}\hat{ల} \\
\infty \\
\infty \\
\hat{~} \\
\underline{0}\end{array}$ & $\begin{array}{l}\mathbf{1} \\
\\
0 \\
\infty \\
\infty \\
\infty \\
m\end{array}$ & $\begin{array}{l}\infty \\
0 \\
0 \\
0 \\
8 \\
0 \\
\text { 1. }\end{array}$ & $\begin{array}{l}\hat{\approx} \\
n \\
0 \\
\ddots \\
\Xi\end{array}$ & $\begin{array}{l}n \\
\sim \\
n \\
\infty \\
\infty \\
\infty\end{array}$ & \begin{tabular}{l}
$\infty$ \\
$\infty$ \\
$\infty$ \\
$\infty$ \\
\multirow{1}{*}{} \\
$\infty$ \\
$\infty$
\end{tabular} & 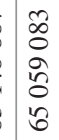 \\
\hline 尽 & $\begin{array}{l}\sqrt{n} \\
i n \\
0 \\
0 \\
r\end{array}$ & 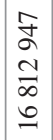 & 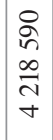 & $\begin{array}{l}\infty \\
0 \\
0 \\
m \\
0 \\
\sim\end{array}$ & $\begin{array}{l}n \\
\delta \\
\dot{0} \\
\tilde{n} \\
n \\
n\end{array}$ & $\begin{array}{l}\infty \\
0 \\
0 \\
0 \\
\sigma \\
\infty\end{array}$ & $\begin{array}{l}\hat{\sigma} \\
\hat{\sigma} \\
\hat{n} \\
\hat{\sigma} \\
\infty\end{array}$ & 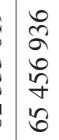 \\
\hline 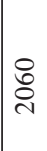 & 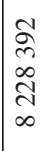 & 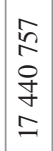 & \begin{tabular}{l}
$n$ \\
$m$ \\
$m$ \\
\multirow{2}{*}{} \\
$i n$ \\
+
\end{tabular} & $\begin{array}{l}\text { O } \\
\text { r } \\
\text { J } \\
\text { N }\end{array}$ & $\begin{array}{l}2 \\
\partial \\
\dot{1} \\
0 \\
2 \\
2\end{array}$ & $\begin{array}{l}\overrightarrow{2} \\
i v \\
b \\
a\end{array}$ & $\begin{array}{l}0 \\
+ \\
\bar{\alpha} \\
\alpha \\
\alpha \\
\alpha\end{array}$ & 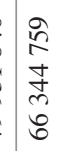 \\
\hline ஜ̊̀ & $\begin{array}{l}8 \\
\stackrel{8}{ } \\
\text { ปे } \\
\infty \\
\infty\end{array}$ & 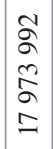 & 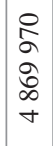 & 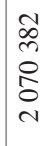 & \begin{tabular}{l}
0 \\
$\infty$ \\
$\sim$ \\
0 \\
0 \\
\multirow{J}{1}{} \\
$\simeq$
\end{tabular} & 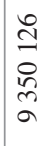 & $\begin{array}{l}\tilde{N} \\
\Sigma \\
乏 \\
乏\end{array}$ & $\begin{array}{l}\hat{\sigma} \\
\infty \\
\infty \\
\delta \\
\delta\end{array}$ \\
\hline 芒 & 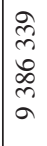 & $\begin{array}{l}\infty \\
0 \\
\infty \\
\infty \\
\qquad \\
\infty \\
\infty\end{array}$ & $\begin{array}{l}\bar{\sigma} \\
\Xi \\
\bar{\Xi}\end{array}$ & 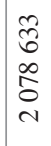 & $\begin{array}{l}\infty \\
\mathbb{N} \\
\hat{N} \\
\tilde{N} \\
=\end{array}$ & $\begin{array}{l}n \\
\text { f } \\
\text { o } \\
n \\
a\end{array}$ & 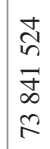 & 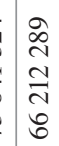 \\
\hline ণ্లి & 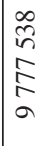 & $\begin{array}{l}\mathcal{\delta} \\
\tilde{n} \\
\tilde{\delta} \\
\delta \\
\Omega\end{array}$ & $\begin{array}{l}2 \\
\tilde{o} \\
0 \\
\mathbf{y} \\
\text { n }\end{array}$ & $\begin{array}{c}\infty \\
i \\
i \\
i \\
\infty \\
0 \\
\sim\end{array}$ & $\begin{array}{l}\hat{\sigma} \\
\infty \\
2 \\
\sigma \\
0\end{array}$ & 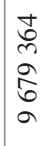 & 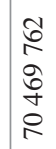 & $\left\{\begin{array}{l}\tilde{N} \\
\tilde{n} \\
n \\
z \\
\tilde{b}\end{array}\right.$ \\
\hline ત્તి & $\begin{array}{l}\stackrel{2}{\sigma} \\
\text { ळે } \\
\stackrel{0}{0}\end{array}$ & $\begin{array}{l}0 \\
0 \\
0 \\
0 \\
0 \\
0 \\
2\end{array}$ & $\begin{array}{c}\hat{N} \\
\tilde{\sigma} \\
\vec{J} \\
\tilde{\sigma}\end{array}$ & 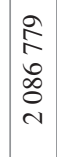 & $\begin{array}{l}\hat{n} \\
\infty \\
n \\
0 \\
0\end{array}$ & $\begin{array}{l}\stackrel{2}{2} \\
2 \\
2 \\
a \\
a\end{array}$ & $\begin{array}{l}\mathfrak{N} \\
\hat{N} \\
\hat{\sigma} \\
\hat{b} \\
0 \\
0\end{array}$ & 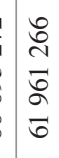 \\
\hline$\stackrel{n}{\stackrel{\sim}{\sim}}$ & $\begin{array}{l}0 \\
n \\
i \\
\infty \\
\infty \\
0\end{array}$ & $\begin{array}{l}\hat{2} \\
\hat{2} \\
\hat{\alpha} \\
2 \\
2\end{array}$ & $\begin{array}{l}\vec{n} \\
\infty \\
0 \\
7 \\
n \\
n\end{array}$ & $\begin{array}{c}= \\
\vec{n} \\
\check{0} \\
0 \\
0 \\
v\end{array}$ & 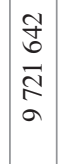 & $\begin{array}{l}\hat{2} \\
\hat{\sigma} \\
\infty \\
\sigma\end{array}$ & 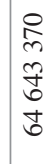 & $\begin{array}{l}8 \\
8 \\
8 \\
z \\
8 \\
8\end{array}$ \\
\hline 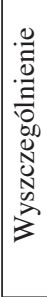 & 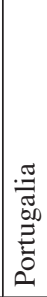 & 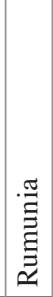 & 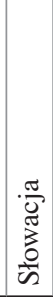 & 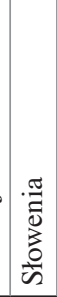 & 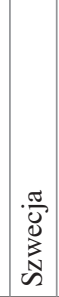 & $\vec{b}$ & 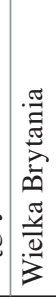 & $\frac{3}{\frac{3}{0}}$ \\
\hline
\end{tabular}




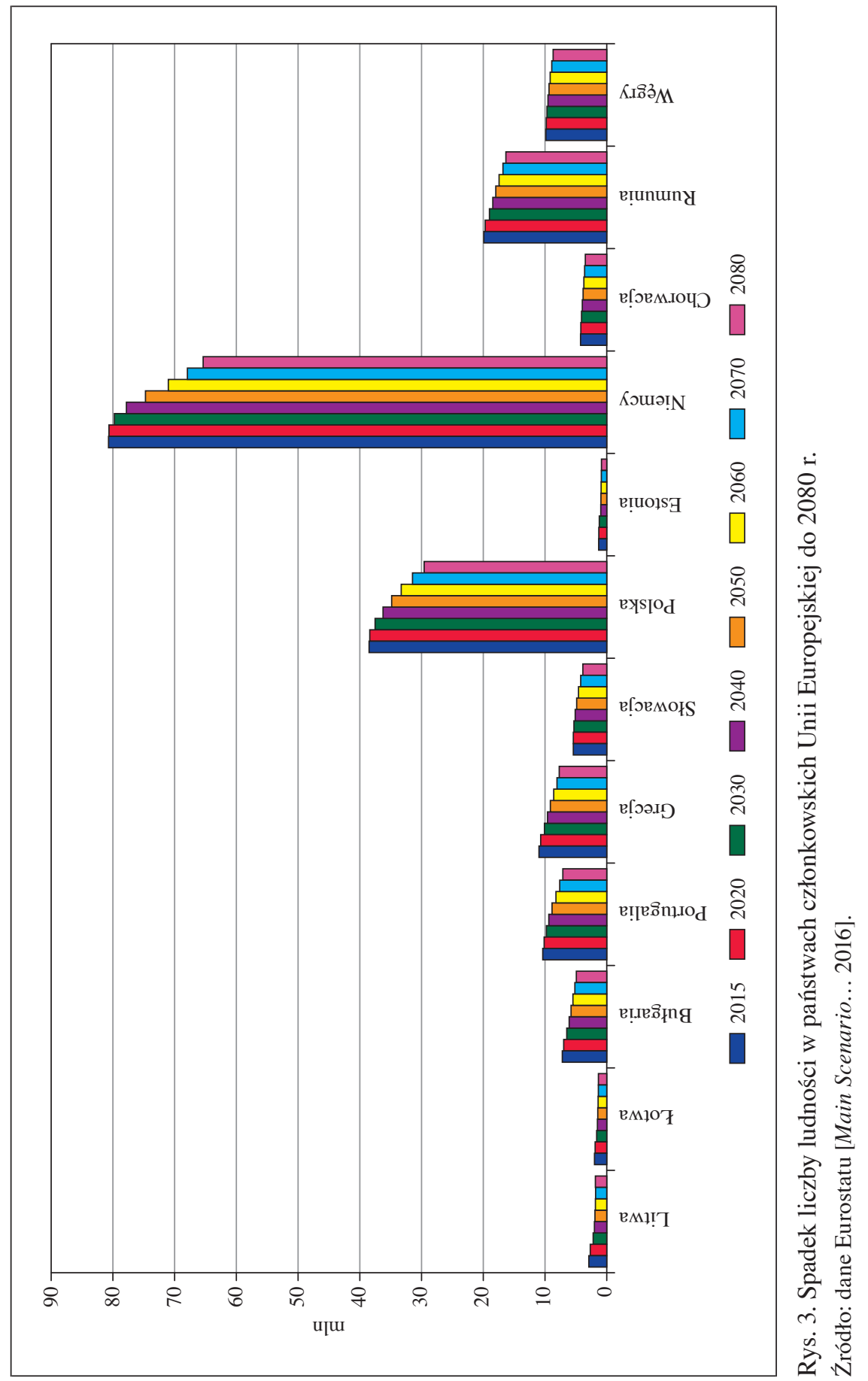


W Polsce, Grecji i Litwie poparcie wynosi odpowiednio 28\%, 27\% i 26\%. Zaledwie kilkunastoprocentowe poparcie dla napływu ludności obcego pochodzenia występuje w takich państwach, jak: Słowacja (17\%), Węgry i Bułgaria (15\%) oraz Łotwa i Estonia (14\%) [Opinia publiczna... 2016].

Tylko władze Niemiec miały pozytywne nastawienie do napływu uchodźców do tego kraju. Nie można już tego natomiast powiedzieć obecnie o jego obywatelach (60\% jest przeciw). W pozostałych państwach, głównie na Węgrzech, w Polsce, Chorwacji oraz Grecji, widać niechęć do przyjmowania uchodźców, zwłaszcza muzułmańskich [EU Refugees... 2016].

Obliczono współczynnik korelacji rang Spearmana dla analizowanych wielkości, tj. prognozowanego spadku liczby ludności do 2080 r. w państwach oraz poparcia opinii publicznej dla napływu ludności obcego pochodzenia. Wartość współczynnika wynosi -0,237762, co oznacza słabą korelację ujemną. Pozytywne nastawienie do napływu imigrantów da się zatem wyjaśnić prognozowanym spadkiem liczby ludności w państwach członkowskich, zależność ta jest jednak słaba.

\section{Wskaźniki obciążenia imigracyjnego i ich wpływ na decyzje o przyjmowaniu ludności obcego pochodzenia}

Dla celów niniejszego opracowania zaproponowano wskaźnik obciążenia imigracyjnego (WOI). Przyjęto, że jest to liczba ubiegających się o azyl ${ }^{7} \mathrm{w}$ danym kraju dzielona przez liczbę ludności tego kraju i pomnożona razy 1000. Wyniki obliczeń dla państw członkowskich Unii Europejskiej w latach 2006-2015 zaprezentowano w tabeli 3.

W latach 2006-2010 najwyższą wartość wskaźnika odnotowano na Cyprze i Malcie, a w latach 2011-2013 w Szwecji, na Malcie, w Luksemburgu oraz Belgii. W okresie obejmującym obecny kryzys imigracyjny, w 2014 r., najwyższą wartość wskaźnika zaobserwowano w Szwecji, następnie na Węgrzech, w Austrii, na Malcie, w Danii i Niemczech. W 2015 r. wskaźnik ten wzrósł kilkakrotnie w porównaniu z latami wcześniejszymi i osiągnął najwyższą wartość na Węgrzech, w Szwecji oraz Austrii. Znacznie wzrosła wartość tego wskaźnika również w Finlandii, Niemczech, Luksemburgu, na Malcie, w Belgii oraz Danii.

Wartość tego wskaźnika w przypadku Węgier jest blisko siedmiokrotnie wyższa od analogicznej wartości dla całej Unii Europejskiej. Należy zaznaczyć, że Węgrzy (85\% obywateli) są przeciwni napływowi imigrantów, co może być tłuma-

${ }^{7}$ Liczba osób ubiegających się o azyl została zaproponowana w konstrukcji tego miernika, ponieważ większość/wszyscy nielegalni imigranci składają wnioski azylowe, z czego ok. $2 \%$ jest rozpatrywanych pozytywnie. Można na tej podstawie wnosić, że $98 \%$ ludności obcej napływającej do UE to nielegalni imigranci. 
czone wysoką wartością wskaźnika obciążenia imigracyjnego. Dla porównania znacznie bardziej przychylne napływowi imigrantów Niemcy (40\% obywateli) charakteryzują się wskaźnikiem ponad trzykrotnie niższym.

Tabela 3. Wskaźnik obciążenia imigracyjnego dla krajów Unii Europejskiej w latach 2006-2015

\begin{tabular}{|c|c|c|c|c|c|c|c|c|c|c|}
\hline WOI & 2006 & 2007 & 2008 & 2009 & 2010 & 2011 & 2012 & 2013 & 2014 & 2015 \\
\hline UE-27 (UE-28) & 0,40 & 0,45 & 0,45 & 0,53 & 0,52 & 0,61 & 0,67 & 0,85 & 1,24 & 2,60 \\
\hline Austria & 1,62 & 1,44 & 1,53 & 1,89 & 1,32 & 1,72 & 2,07 & 2,07 & 3,30 & 10,28 \\
\hline Belgia & 0,84 & 1,09 & 1,42 & 2,01 & 2,41 & 2,90 & 2,53 & 1,88 & 2,03 & 3,97 \\
\hline Bułgaria & 0,07 & 0,11 & 0,10 & 0,11 & 0,14 & 0,12 & 0,19 & 0,98 & 1,53 & 2,83 \\
\hline Chorwacja & 0,00 & 0,00 & 0,00 & 0,00 & 0,00 & 0,00 & 0,00 & 0,25 & 0,11 & 0,05 \\
\hline Cypr & 6,10 & 8,95 & 5,05 & 4,02 & 3,51 & 2,11 & 1,90 & 1,45 & 2,03 & 2,67 \\
\hline Czechy & 0,27 & 0,15 & 0,16 & 0,12 & 0,07 & 0,07 & 0,07 & 0,07 & 0,11 & 0,14 \\
\hline Dania & 0,36 & 0,41 & 0,43 & 0,67 & 0,92 & 0,71 & 1,08 & 1,28 & 2,61 & 3,70 \\
\hline Estonia & 0,00 & 0,01 & 0,01 & 0,03 & 0,03 & 0,05 & 0,06 & 0,07 & 0,12 & 0,18 \\
\hline Finlandia & 0,43 & 0,27 & 0,69 & 0,92 & 0,58 & 0,54 & 0,57 & 0,59 & 0,66 & 5,91 \\
\hline Francja & 0,49 & 0,46 & 0,65 & 0,74 & 0,82 & 0,88 & 0,94 & 1,01 & 0,98 & 1,14 \\
\hline Grecja & 1,11 & 2,28 & 1,80 & 1,44 & 0,92 & 0,84 & 0,86 & 0,75 & 0,86 & 1,22 \\
\hline Hiszpania & 0,12 & 0,16 & 0,10 & 0,06 & 0,06 & 0,07 & 0,05 & 0,10 & 0,12 & 0,32 \\
\hline Holandia & 0,89 & 0,43 & 0,93 & 0,98 & 0,91 & 0,88 & 0,78 & 0,78 & 1,46 & 2,66 \\
\hline Irlandia & 1,01 & 0,91 & 0,86 & 0,59 & 0,43 & 0,28 & 0,21 & 0,21 & 0,31 & 0,71 \\
\hline Litwa & 0,04 & 0,04 & 0,16 & 0,14 & 0,16 & 0,17 & 0,21 & 0,13 & 0,15 & 0,11 \\
\hline Luksemburg & 1,12 & 0,89 & 0,94 & 0,97 & 1,55 & 4,20 & 3,91 & 1,99 & 2,09 & 4,45 \\
\hline Łotwa & 0,00 & 0,02 & 0,03 & 0,03 & 0,03 & 0,16 & 0,10 & 0,10 & 0,19 & 0,17 \\
\hline Malta & 3,14 & 3,40 & 6,39 & 5,80 & 0,42 & 4,55 & 4,98 & 5,33 & 3,17 & 4,30 \\
\hline Niemcy & 0,26 & 0,23 & 0,33 & 0,40 & 0,59 & 0,66 & 0,96 & 1,57 & 2,51 & 5,87 \\
\hline Polska & 0,11 & 0,19 & 0,22 & 0,28 & 0,17 & 0,18 & 0,28 & 0,40 & 0,21 & 0,32 \\
\hline Portugalia & 0,01 & 0,02 & 0,02 & 0,01 & 0,01 & 0,03 & 0,03 & 0,05 & 0,04 & 0,09 \\
\hline Rumunia & 0,02 & 0,03 & 0,06 & 0,05 & 0,04 & 0,09 & 0,12 & 0,07 & 0,08 & 0,06 \\
\hline Słowacja & 0,53 & 0,49 & 0,17 & 0,15 & 0,10 & 0,09 & 0,14 & 0,08 & 0,06 & 0,06 \\
\hline Słowenia & 0,25 & 0,18 & 0,13 & 0,09 & 0,12 & 0,17 & 0,14 & 0,13 & 0,19 & 0,13 \\
\hline Szwecja & 2,69 & 3,97 & 2,70 & 2,61 & 3,41 & 3,15 & 4,62 & 5,68 & 8,42 & 16,67 \\
\hline Węgry & 0,21 & 0,34 & 0,32 & 0,47 & 0,21 & 0,17 & 0,22 & 1,91 & 4,33 & 17,97 \\
\hline Wielka Brytania & 0,47 & 0,46 & 0,00 & 0,51 & 0,39 & 0,43 & 0,45 & 0,48 & 0,51 & 0,60 \\
\hline Włochy & 0,18 & 0,24 & 0,51 & 0,30 & 0,17 & 0,68 & 0,29 & 0,45 & 1,06 & 1,38 \\
\hline
\end{tabular}

Źródło: opracowanie własne na podstawie danych Eurostatu. 
Obliczono współczynniki korelacji rang Spearmana i Pearsona dla 12 państw, w których prognozowany spadek liczby ludności jest największy. Następnie obliczono korelacje między wskaźnikiem obciążenia imigracją a poziomem akceptacji społeczeństw dla napływu ludności obcego pochodzenia. Oba współczynniki wykazały słabą korelację ujemną (współczynnik Spearmana jest równy -0,33, natomiast współczynnik Pearsona wynosi -0,24). Oznacza to, że im większe jest obciążenie państwa napływem imigrantów, tym mniejsze jest poparcie opinii publicznej dla tego zjawiska.

\section{Wskaźniki obciążenia gospodarek napływem imigrantów}

W niniejszym opracowaniu zaproponowano też drugi wskaźnik mogący wyjaśnić nastawienie państw członkowskich do przyjmowania ludności obcego pochodzenia. Jest to wskaźnik obciążenia gospodarek napływem imigrantów i uchodźców (WOG). Jest to poprzedni wskaźnik obciążenia imigracyjnego (WOI) podzielony przez PKB per capita danego kraju według parytetu siły nabywczej (dla UE-28 = 100) i pomnożony przez 100 . Analizuje on w sposób uproszczony możliwości ekonomiczne, ale również relatywne obciążenie ekonomiczne krajów, do których napływają imigranci. Wyniki analizy zostały zaprezentowane w tabeli 4 .

Tabela 4. Wskaźnik obciążenia gospodarczego dla krajów Unii Europejskiej w latach 2006-2015

\begin{tabular}{|l|c|c|c|c|c|c|c|c|c|c|}
\hline \multicolumn{1}{|c|}{ WOG } & 2006 & 2007 & 2008 & 2009 & 2010 & 2011 & 2012 & 2013 & 2014 & 2015 \\
\hline UE-27 (UE-28) & 0,40 & 0,45 & 0,45 & 0,53 & 0,52 & 0,61 & 0,67 & 0,85 & 1,24 & 2,60 \\
\hline Austria & 1,29 & 1,17 & 1,23 & 1,51 & 1,05 & 1,36 & 1,58 & 1,58 & 2,55 & 8,09 \\
\hline Belgia & 0,73 & 0,95 & 1,25 & 1,73 & 2,02 & 2,44 & 2,11 & 1,57 & 1,72 & 3,39 \\
\hline Bułgaria & 0,17 & 0,26 & 0,22 & 0,25 & 0,31 & 0,27 & 0,41 & 2,13 & 3,25 & 6,15 \\
\hline Chorwacja & 0,00 & 0,00 & 0,00 & 0,00 & 0,00 & 0,00 & 0,00 & 0,43 & 0,18 & 0,09 \\
\hline Cypr & 6,16 & 8,95 & 4,81 & 3,82 & 3,44 & 2,20 & 2,08 & 1,73 & 2,48 & 3,30 \\
\hline Czechy & 0,33 & 0,19 & 0,20 & 0,14 & 0,09 & 0,09 & 0,09 & 0,08 & 0,13 & 0,17 \\
\hline Dania & 0,29 & 0,34 & 0,35 & 0,55 & 0,73 & 0,57 & 0,86 & 1,02 & 2,09 & 2,98 \\
\hline Estonia & 0,01 & 0,02 & 0,02 & 0,05 & 0,04 & 0,07 & 0,08 & 0,10 & 0,15 & 0,24 \\
\hline Finlandia & 0,38 & 0,23 & 0,58 & 0,79 & 0,50 & 0,47 & 0,50 & 0,52 & 0,60 & 5,47 \\
\hline Francja & 0,45 & 0,43 & 0,62 & 0,69 & 0,76 & 0,82 & 0,88 & 0,94 & 0,91 & 1,08 \\
\hline Grecja & 1,19 & 2,47 & 1,91 & 1,53 & 1,06 & 1,09 & 1,17 & 1,01 & 1,18 & 1,71 \\
\hline Hiszpania & 0,12 & 0,16 & 0,10 & 0,06 & 0,06 & 0,08 & 0,06 & 0,11 & 0,13 & 0,35 \\
\hline Holandia & 0,66 & 0,32 & 0,67 & 0,71 & 0,68 & 0,65 & 0,59 & 0,59 & 1,11 & 2,06 \\
\hline Irlandia & 0,69 & 0,62 & 0,66 & 0,46 & 0,33 & 0,21 & 0,16 & 0,16 & 0,23 & 0,49 \\
\hline
\end{tabular}


cd. tabeli 4

\begin{tabular}{|l|c|c|c|c|c|c|c|c|c|c|}
\hline \multicolumn{1}{|c|}{ WOG } & 2006 & 2007 & 2008 & 2009 & 2010 & 2011 & 2012 & 2013 & 2014 & 2015 \\
\hline Litwa & 0,08 & 0,06 & 0,26 & 0,25 & 0,26 & 0,26 & 0,31 & 0,18 & 0,20 & 0,15 \\
\hline Luksemburg & 0,44 & 0,34 & 0,37 & 0,39 & 0,61 & 1,60 & 1,51 & 0,75 & 0,79 & 1,64 \\
\hline Łotwa & 0,01 & 0,03 & 0,04 & 0,05 & 0,06 & 0,29 & 0,17 & 0,16 & 0,29 & 0,26 \\
\hline Malta & 4,02 & 4,36 & 7,98 & 6,91 & 0,49 & 5,42 & 5,93 & 6,20 & 3,69 & 4,83 \\
\hline Niemcy & 0,22 & 0,20 & 0,28 & 0,35 & 0,49 & 0,54 & 0,78 & 1,27 & 1,99 & 4,69 \\
\hline Polska & 0,22 & 0,36 & 0,41 & 0,47 & 0,28 & 0,28 & 0,43 & 0,60 & 0,31 & 0,46 \\
\hline Portugalia & 0,02 & 0,03 & 0,02 & 0,02 & 0,02 & 0,03 & 0,04 & 0,06 & 0,05 & 0,11 \\
\hline Rumunia & 0,05 & 0,08 & 0,12 & 0,10 & 0,09 & 0,17 & 0,23 & 0,14 & 0,14 & 0,11 \\
\hline Słowacja & 0,86 & 0,73 & 0,23 & 0,21 & 0,14 & 0,12 & 0,18 & 0,11 & 0,08 & 0,08 \\
\hline Słowenia & 0,29 & 0,21 & 0,14 & 0,11 & 0,14 & 0,21 & 0,18 & 0,16 & 0,23 & 0,16 \\
\hline Szwecja & 2,15 & 3,13 & 2,14 & 2,14 & 2,73 & 2,50 & 3,64 & 4,58 & 6,84 & 13,55 \\
\hline Węgry & 0,34 & 0,56 & 0,50 & 0,73 & 0,32 & 0,26 & 0,33 & 2,89 & 6,37 & 26,43 \\
\hline Wielka Brytania & 0,38 & 0,39 & 0,00 & 0,46 & 0,36 & 0,40 & 0,42 & 0,44 & 0,47 & 0,54 \\
\hline Włochy & 0,17 & 0,23 & 0,49 & 0,29 & 0,16 & 0,67 & 0,29 & 0,46 & 1,11 & 1,46 \\
\hline
\end{tabular}

Źródło opracowanie własne na podstawie danych Eurostatu.

W latach 2006-2009 najwyższą wartość wskaźnika zanotowano na Cyprze i Malcie, a w latach 2010-2013 na Malcie i w Szwecji. Wysokie wartości WOG w 2014 r. wystąpiły w Szwecji oraz na Węgrzech. W 2015 r., podobnie jak w przypadku wskaźnika WOI, stwierdzono w niektórych państwach znaczny wzrost jego wartości. Najwyższy poziom WOG odnotowano w przypadku Węgier, Szwecji, Austrii, Bułgarii, Finlandii, Malty oraz Niemiec. Nieco niższy jego poziom zaobserwowano w Belgii oraz na Cyprze.

Wartość wskaźnika w przypadku Węgier jest ponad dziesięciokrotnie wyższa od wartości dla całej Unii Europejskiej. Jak już wspomniano, Węgrzy są przeciwni napływowi imigrantów, co może być tłumaczone wysoką wartością wskaźnika obciążenia gospodarczego. Dla porównania znacznie bardziej przychylni napływowi imigrantów są Niemcy, a wskaźnik dla tego kraju jest ponad pięciokrotnie niższy.

Obliczono współczynniki korelacji rang Spearmana i Pearsona dla 12 państw, w których prognozowany spadek liczby ludności jest największy. Obliczono korelacje między wskaźnikiem obciążenia gospodarczego a poziomem akceptacji społeczeństw dla napływu ludności obcego pochodzenia. Oba współczynniki wykazały słabą korelację ujemną (współczynnik Spearmana jest równy $-0,33$, natomiast współczynnik Pearsona wynosi -0,32). Oznacza to, że im większe jest obciążenie gospodarki państwa napływem imigrantów, tym mniejsze jest poparcie opinii publicznej dla tego zjawiska. 


\section{Porównanie wartości wskaźników WOI i WOG}

Kolejnym etapem analizy jest porównanie wartości obu wskaźników - obciążenia imigracyjnego i obciążenia gospodarczego krajów, w których złożono najwięcej wniosków azylowych w 2015 r. Wyniki zaprezentowano na rys. 4.

Węgry są krajem, w którym poziom obu wskaźników jest najwyższy, co oznacza największe w Unii Europejskiej obciążenie zarówno w stosunku do liczby ludności, jak i potencjału gospodarczego mierzonego wskaźnikiem PKB per capita według parytetu siły nabywczej. Obciążenie gospodarcze jest znacznie większe niż stosunek liczby składanych wniosków o udzielenie azylu do liczby mieszkańców.

Wysoki poziom obu wskaźników występuje ponadto w Szwecji, Austrii, Finlandii i Niemczech. Niższy poziom wskaźników można zaobserwować w Luksemburgu, na Malcie, w Belgii, Danii, Bułgarii, na Cyprze i w Holandii. W większości wymienionych krajów wysokość wskaźnika obciążenia gospodarczego jest jednak niższa od wskaźnika obciążenia imigracyjnego w stosunku do liczby ludności. Potwierdza to częściowo tezę, że kraje bogate są znacznie częściej wybierane jako kraje docelowe imigracji, ale równocześnie stanowi to mniejsze obciążenie dla ich gospodarek. Dlatego też nie są one tak bardzo nieprzychylne napływowi imigrantów i uchodźców jak nowe państwa członkowskie Unii Europejskiej, szczególnie Węgry.

W niektórych państwach członkowskich napływ imigrantów i uchodźców od 2006 r. nie przekracza średniej unijnej. Do państw tych należą: Czechy, Estonia, Irlandia, Hiszpania, Chorwacja, Łotwa, Litwa, Polska, Portugalia, Rumunia, Słowenia i Słowacja.

W całym analizowanym okresie następował wzmożony napływ imigrantów i uchodźców do Szwecji, Austrii, na Maltę, do Belgii, na Cypr i do Grecji. W przypadku tego ostatniego kraju oba wskaźniki nie przekroczyły ich średnich wartości dla Unii Europejskiej. W przypadku Szwecji obserwowano wartości WOI i WOG równe odpowiednio 6,4 oraz 5,2 średniej unijnej. W Austrii było to blisko 4 oraz 3 razy więcej niż średnia unijna. W pozostałych państwach tej grupy, obciążenie imigracyjne wynosiło od 1,5 do 2 razy więcej niż średnia unijna.

W przypadku Bułgarii, Włoch, Danii, Niemiec, Luksemburga, Węgier i Holandii wzmożony napływ imigrantów i uchodźców rozpoczął się w ostatnich latach, tj. 2013-2014, i związany jest z kryzysem imigracyjnym. Analiza wskaźników obciążenia imigracyjnego i wskaźników obciążenia gospodarek imigrantami wskazuje, że najtrudniejsza sytuacja występuje na Węgrzech, gdzie wartość wskaźników jest wyższa odpowiednio 7- i 10-krotnie od średniej unijnej. W Niemczech jest wyższa ok. 2 razy, a w pozostałych krajach, z wyjątkiem Bułgarii (gdzie wartość $W O G$ jest wyższa 2,5 razy od średniej unijnej), obciążenie imigracyjne jest mniejsze. 


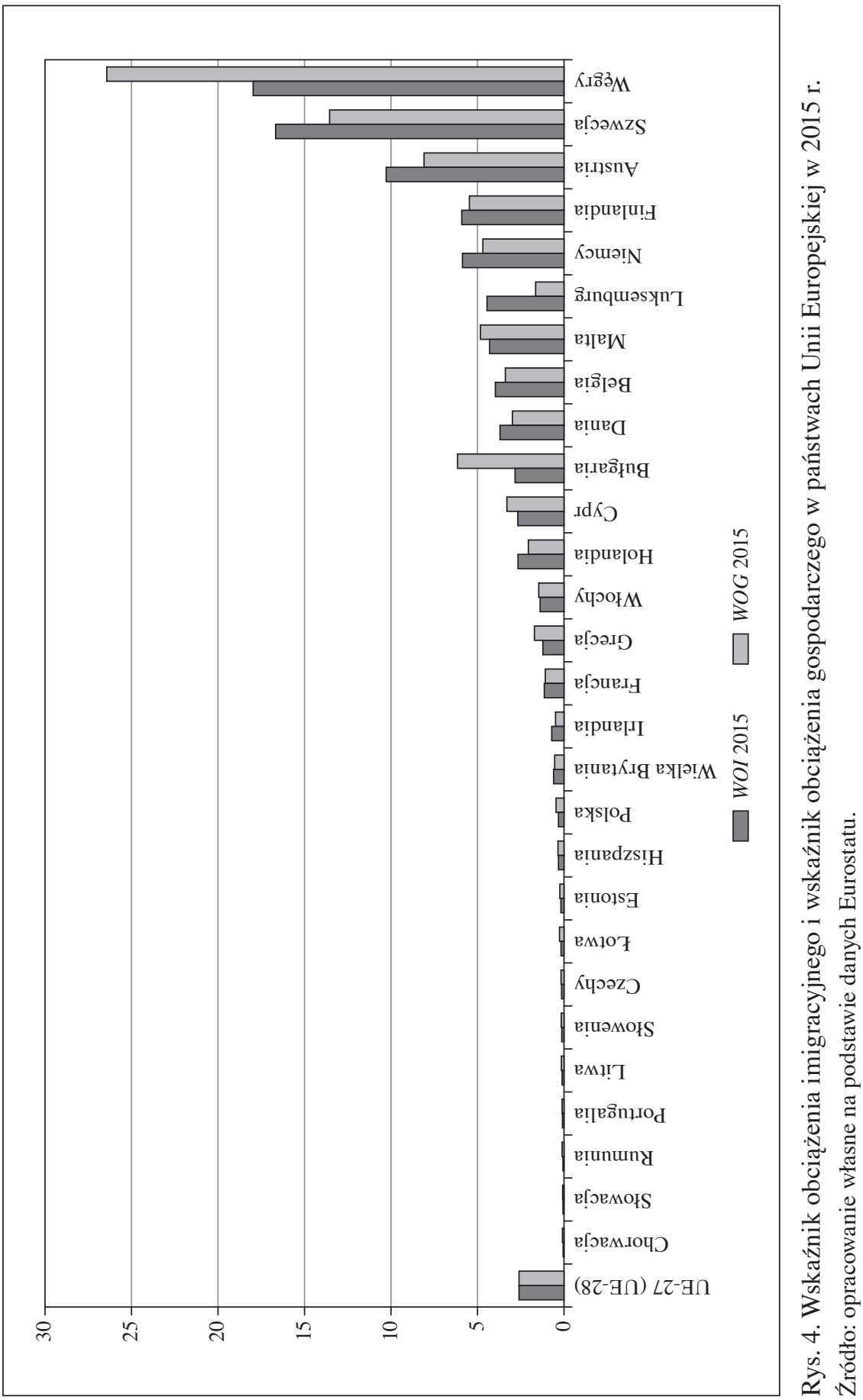




\section{Wnioski}

Próba zastosowania mierników ilościowych do wyjaśnienia przyczyn pozytywnego nastawienia państw członkowskich Unii Europejskiej do napływu imigrantów pozwala jedynie na częściowe wyjaśnienie analizowanego problemu. Hipoteza pierwsza zakładała, że pozytywne podejście do napływu imigrantów występuje w państwach, w których prognozowany jest największy spadek ludności do 2080 r. Wśród państw najbardziej zagrożonych znacznym spadkiem liczby ludności jest dziewięć „,nowych” państw członkowskich UE oraz trzy „stare”. Współczynnik korelacji rang Spearmana między analizowanymi wielkościami, tj. prognozowanym spadkiem liczby ludności do 2080 r. w tych państwach a poparciem opinii publicznej dla napływu ludności obcego pochodzenia, wynosi $-0,237762$ (słaba korelacja ujemna). Oznacza to, że pozytywne nastawienie do napływu imigrantów można wyjaśnić prognozowanym spadkiem liczby ludności w państwach członkowskich, ale zależność ta jest słaba.

Hipoteza druga zakładała, że pozytywne nastawienie do napływu imigrantów występuje w państwach, w których wskaźnik obciążenia imigracyjnego jest niższy od średniej unijnej. Wartość tego wskaźnika w przypadku Węgier okazała się blisko siedmiokrotnie wyższa od wartości dla całej Unii Europejskiej, co może tłumaczyć fakt, że 85\% Węgrów jest przeciwnych napływowi imigrantów. Znacznie przychylniejsze napływowi imigrantów Niemcy (40\% obywateli) charakteryzują się wskaźnikiem ponad trzykrotnie niższym. Współczynniki korelacji rang Spearmana i Pearsona dla 12 państw, w których prognozowany spadek liczby ludności jest największy, wykazały słabą korelację ujemną (współczynnik Spearmana jest równy $-0,33$, natomiast współczynnik Pearsona wynosi -0,24). Oznacza to, że im większe jest obciążenie państwa napływem imigrantów, tym mniejsze jest poparcie opinii publicznej dla tego zjawiska.

Hipoteza trzecia zakładała, że pozytywne nastawienie do napływu imigrantów występuje w państwach, w których wskaźnik obciążenia gospodarczego napływem obcej ludności jest niższy od średniej unijnej. Na Węgrzech, gdzie wielu jest przeciwników napływu imigrantów, wartość tego wskaźnika jest ponad dziesięciokrotnie wyższa od wartości dla całej Unii Europejskiej. Niemcy charakteryzują się wskaźnikiem ponad pięciokrotnie niższym, a ich nastawienie do napływu imigrantów jest dużo bardziej pozytywne. Współczynniki korelacji rang Spearmana i Pearsona dla 12 państw, w których prognozowany spadek liczby ludności jest największy, wykazały słabą korelację ujemną (współczynnik Spearmana jest równy $-0,33$, natomiast współczynnik Pearsona wynosi -0,32). Oznacza to, że im większe jest obciążenie gospodarki państwa napływem imigrantów, tym mniejsze jest poparcie opinii publicznej dla tego zjawiska. 


\section{Literatura}

Białocerkiewicz J. [2002], Status prawny cudzoziemca w świetle standardów międzynarodowych, UMK, Toruń.

Borjas G. [1989], Economic Theory and International Migration, „International Migration Review", vol. 23, nr 3, https://doi.org/10.2307/2546424.

Castles S., Miller M.J. [2011], Migracje we współczesnym świecie, Wydawnictwo Naukowe PWN, Warszawa.

EU Refugees and National Identity Report [2016], Global Attitudes Survey, Pew Research Center, http://www.pewglobal.org/files/2016/07/Pew-Research-Center-EU-Refugeesand-National-Identity-Report-FINAL-July-11-2016.pdf (data dostępu: 15.10.2016).

Florczak A. [2002], Uchodźcy w Polsce. Między humanitaryzmem a pragmatyzmem, Wydawnictwo Adam Marszałek, Toruń.

Janicki W. [2007], Przeglq̨d teorii migracji ludności, „Annales Universitatis Mariae Curie-Sklodowska", sec. B, vol. 62.

Kelm H. [2014], Kryzys demograficzny w Unii Europejskiej [w:] Kryzys Unii czy kryzys w Unii? Kierunki dyskusji nad przyszłościq integracji europejskiej, red. H. Tendera-Właszczuk, Difin, Warszawa.

Kelm H., Tendera-Właszczuk H. [2008], Polityka Unii Europejskiej wobec imigrantów, „Zeszyty Naukowe Uniwersytetu Ekonomicznego w Krakowie”, nr 787.

Kelm H., Tendera-Właszczuk H. [2011], Analiza sytuacji uchodźców w Polsce w aspekcie realizacji wspólnej polityki azylowej Unii Europejskiej, ,Zeszyty Naukowe Uniwersytetu Ekonomicznego w Krakowie", nr 852.

Komunikat prasowy Komisji Europejskiej z dnia 22 grudnia 2016 r. [2016], nr IP/16/4493. Konwencja dotycząca statusu uchodźców, sporządzona w Genewie dnia 28 lipca 1951 r. [1951], Dz.U. 1991, nr 119 poz. 515.

Lee E.S. [1966], A Theory of Migration, „Demography“, vol. 3, nr 1, https://doi.org/ $10.2307 / 2060063$.

Lee E.S. [1972], Teorie migracji [w:] Modele migracji, red. A.S. Ostrowicki, Warszawa.

Main Scenario - Projected Demographic Balances and Indicators, http://appsso.eurostat. ec.europa.eu/nui/show.do? dataset=proj_13ndbims\&lang=en (data dostępu: 7.11.2016).

Massey D.S., Arango J., Hugo G., Kouaouci A., Pellegrino A., Taylor J.E. [1993], Theories of International Migration: Review and Appraisal, „Population and Development Review", vol. 19, nr 3, https://doi.org/10.2307/2938462.

The Mediterranean Migration Crisis. Why People Flee, What the EU Should Do [2015], Human Rights Watch, https://www.hrw.org/report/2015/06/19/mediterranean-migration-crisis/why-people-flee-what-eu-should-do\#page (data dostępu: 12.11.2016).

Opinia publiczna w Unii Europejskiej. Raport krajowy. Polska [2016], Standardowy Eurobarometr 86, https://ec.europa.eu/poland/sites/poland/files/170306_st86_report. pdf (data dostępu: 12.11.2016).

Protokół dotyczący statusu uchodźców, sporządzony w Nowym Jorku dnia 31 stycznia 1967 r. [1967], Dz.U. 1991, nr 119 poz. 517.

Tendera-Właszczuk H. [2016], Kryzys migracyjny zagrożeniem dla realizacji projektu zjednoczonej Europy, „Krakowskie Studia Międzynarodowe”, t. XIII, nr 3.

Wallerstein I. [1974], The Modern World System, Capitalist Agriculture and the Origins of the European World Economy in the Sixteenth Century, New York Academic Press, New York. 


\section{Analysis of the Causes of a Different Approach to the Inflow of Immigrants in the European Union Member States}

(Abstract)

The influx of illegal immigration to the European Union has grown rapidly over the past few years. Member States' official stances and policies differ considerably as to whether to accept or reject refugees and illegal immigrants. Using a quantitative analysis, the article examines the causes of the different approaches to immigration to the EU Member States. It provides a general overview of the demographic forecasts until 2080 and suggests two new indicators to explain the acceptance (or rejection) of foreigners. It follows from the considerations that quantitative indicators are insufficient in determining whether to have a positive or negative position with regard to accepting immigrants to EU Member States.

Keywords: European Union, migration crisis, theories of migration, migration research. 